(A)

\title{
Day vs. night: the importance of the circadian cycle over metacommunities and predator-prey densities
}

\section{Paulo V. Parecis-Silva, Felipe M. Nuvoloni \& Reinaldo J. F. Feres}

To cite this article: Paulo V. Parecis-Silva, Felipe M. Nuvoloni \& Reinaldo J. F. Feres (2016) Day vs. night: the importance of the circadian cycle over metacommunities and predator-prey densities, International Journal of Acarology, 42:3, 141-148, DOI: 10.1080/01647954.2016.1149220

To link to this article: https://doi.org/10.1080/01647954.2016.1149220

曲 Published online: 22 Feb 2016.

Submit your article to this journal $\widetilde{ }$

Џ Article views: 99

View Crossmark data \ulcorner

Citing articles: 2 View citing articles ๘ 


\title{
Day vs. night: the importance of the circadian cycle over metacommunities and predator-prey densities
}

\author{
Paulo V. Parecis-Silva ${ }^{a}$, Felipe M. Nuvoloni ${ }^{\mathrm{b}}$ and Reinaldo J. F. Feres ${ }^{c}$ \\ aPaulo Vittor Parecis-Silva - Programa de Pós-Graduação em Biologia Animal, Instituto de Biociências, Letras e Ciências Exatas, Universidade

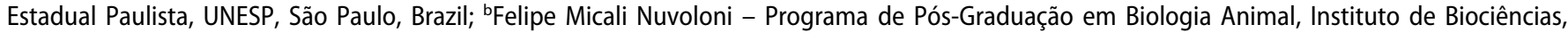 \\ Letras e Ciências Exatas, Universidade Estadual Paulista, UNESP, São Paulo, Brazil; 'Reinaldo José Fazzio Feres - Departamento de Zoologia e \\ Botânica, Instituto de Biociências, Letras e Ciências Exatas, Universidade Estadual Paulista, UNESP, São José do Rio Preto, Brazil
}

\begin{abstract}
Hypothesizing that assembly of mites diverges between sampling periods, our goal was to verify the relative influence of day and night time, climatic parameters and seasonality on the metacommunities of mites associated with Genipa americana L. in Brazil, and on the foraging behaviour of the most abundant predator and phytophagous species. Seasonal variation was a key parameter in metacommunity structure and population dynamics. In contrast, day and night periods and climatic factors had a low importance for most of the response variables, apart from richness that was negatively influenced by temperature. Concerning the population dynamics, time period plays an important role in predator species, but not in phytophagous species. Our results showed that phytophagous mites remain on leaves during both periods, whereas predators seemed to have partitioned their habitat, since some species had a tendency to forage on leaves during the day, while others forage at night. Our finding can be an indicative of behavioural response to intraguild predation or competition. In terms of metacommunity structure and dynamics, sampling period seemed not to affect species composition since we recorded higher turnover rates among trees than between periods in a same tree.
\end{abstract}

\section{ARTICLE HISTORY}

Received 4 November 2015

Accepted 27 January 2016

Published online

22 February 2016

\section{KEYWORDS}

Acari; day-night turnover; night-time samplings; population dynamics; predator trade-off

\section{Introduction}

Studies of community ecology during the day and night have been conducted on various groups of arthropods, and showed differences in the community structure between the two periods (Hassan and Rashid 1997; Basset et al. 2003). Day and night periods may harbour a similar composition of arthropod species; however, foraging activity or a particular behaviour may be more pronounced in one of the periods (Novotny et al. 1999; Saigusa et al. 2000). For example, Novotny et al. (1999) found that the behaviour of different species of ants is directed by the time of day, since Tapinoma melanocephalum (Fabricius) was more active during the day, whereas Crematogaster sp. presented preference for foraging at night.

As different groups of arthropods may have contrasting behaviour between periods of the day and night (Pinto-Leite and Rocha 2012), it is plausible to hypothesize that groups of mites also diverge in some aspects between day and night. Thus, knowledge about mite species composition, abundance and diversity would be refined. Moreover, comparison between diurnal and nocturnal mite communities may elucidate their distribution patterns. Onzo et al. (2003) studied the relationship between phytophagous and predatory mites, and noticed that the predatory mite, Typhlodromalus aripo De Leon was more abundant in the apex of cassava plants during the day and move out to the young leaves at night. In contrast, the phytophagous mite, Mononychellus tanajoa (Bondar) was not found in the apex of the plant, but only on older leaves. Thus, research that focuses the results obtained during diurnal and nocturnal sampling of fauna becomes necessary, due to the lack of knowledge on the influence of time period on community structure.

Our survey was conducted in metacommunities of mites associated with specimens of the Brazilian genipap (Genipa americana L., Rubiaceae) that served as the study model. In this case, we assumed that each site works as a metacommunity, with trees acting as local assemblages. G. americana is a late successional tree species, originated from Central America and distributed in tropical regions (Francis 1993), including throughout Brazil (Carvalho et al. 2004). Despite its wide distribution in the Neotropics, there are few studies of the mite fauna associated with this plant species (Castro and Vieira 2011; Rezende and Lofego 2011). The genipap leaves do not present differential resources or attractive structures for the mites, such as trichomes, extrafloral nectaries or domatia (Valeri et al. 2003), which in turn could mediate a more intrinsic interaction among them (Romero and Benson 2005).

Thus, considering that assembly of mites tend to vary along day and night periods and maybe constitute apart communities, our goal was to verify the relative influence of the time period on some aspects of metacommunities of mites. Besides that, we investigated the related importance of the time period in conjunction with climatic parameters, and seasonality on the foraging behaviour of the most abundant predator and phytophagous species found on G. americana.

\section{Materials and methods}

\section{Study area}

The research was conducted from July 2012 to June 2013 at three sites in São José do Rio Preto municipality. The first site was located at the "Instituto de Biociências, Letras e Ciências Exatas" of Universidade Estadual Paulista, UNESP (Arboretum: $20^{\circ} 47^{\prime} 14^{\prime \prime} S$, $\left.49^{\circ} 21^{\prime} 37^{\prime \prime} \mathrm{W}\right)$. The other two were located at the "Bosque Municipal" in São José do Rio Preto, SP (Forest Grove 1: $20^{\circ}$ $46^{\prime} 46^{\prime \prime} \mathrm{S}, 49^{\circ} 21^{\prime} 15^{\prime \prime} \mathrm{W}$ and Forest Grove 2: $20^{\circ} 46^{\prime} 32^{\prime \prime} \mathrm{S}, 49^{\circ} 21^{\prime} 12^{\prime \prime} \mathrm{W}$ ).

The Arboretum covered about $1000 \mathrm{~m}^{2}$ and was located $2 \mathrm{~km}$ away from the "Bosque Municipal". Forest Grove 1 and Forest Grove 2 , with about $55,000 \mathrm{~m}^{2}$ and $75,000 \mathrm{~m}^{2}$, respectively, were located in the "Bosque Municipal" and separated from each other by two large 
ponds and a bamboo forest that acted as a windbreak. The sampling sites were not exposed to artificial illumination at night-time, and did not differ in terms of environmental, soil or climatic condition.

The local vegetation was considered a seasonal semideciduous forest, being a remaining area of the primary forest of the region, now in the secondary succession due to anthropogenic changes (SMA/IF 2005). Forest Grove 1 had dense vegetation, with jointed branches of the emergent trees, the understory was somewhat dark and saplings and grasses composed the grass layer. Furthermore, this area was located in the highest region of the site. Forest Grove 2 had relatively open vegetation; the emergent trees were scattered, joined by climbers. Moreover, this area was located in the lowest level of the site (Iturralde and Trueba 2001). The Arboretum presented similar vegetation characteristics described for Forest Groove 2. The region's annual mean temperature ranged between $22^{\circ} \mathrm{C}$ and $23^{\circ} \mathrm{C}$ with a well-defined rainy season between October and March. Moreover, this region has a pronounced dry season between April and September, when only $15 \%$ of the total annual rainfall of $1100 \mathrm{~mm}( \pm 225 \mathrm{~mm})$ occurs (Barcha and Arid 1971).

\section{Samplings and mite identification}

Samplings were carried out monthly in mature trees of $G$. americana at the three sites, from which seven trees were selected and marked, totalling 21 trees. Each site was assumed as a distinct metacommunity, with trees acting as local assemblages with hundreds of patches (leaves) that were habitat for the mites. In each tree, 10 leaves were randomly collected around the crown, whose diameter averaged $25 \mathrm{~cm}$. The areas were always sampled in the same order: Arboretum, Forest Grove 1 and Forest Grove 2. The diurnal samplings began at around $8 \mathrm{am}$ in the Arboretum, 9 am in Forest Grove 1 and $10 \mathrm{am}$ in Forest Grove 2, whereas nocturnal samplings began at around $9 \mathrm{pm}$ in the Arboretum, $10 \mathrm{pm}$ in Forest Grove 1 and $11 \mathrm{pm}$ in Forest Grove 2. No severe climatic conditions (i.e. storm and strong winds) were noticed between the diurnal and nocturnal samplings on the same day. Relative humidity and temperature were recorded in the plots, during collection of the samples, using a digital thermohygrometer at $1.50 \mathrm{~m}$ high close to each tree, usually on a shaded spot.

Leaves were placed in plastic bags and taken to the "Laboratório de Acarologia", at UNESP, São José do Rio Preto, where they were stored in the refrigerator at about $10^{\circ} \mathrm{C}$ for up to 1 week for sorting. During this period, the material was examined under a stereoscope and all mites found on both sides of the leaves, except Oribatida, were mounted on microscope slides with Hoyer's medium (Moraes and Flechtmann 2008) and subsequently counted. The oribatid mites were removed with a bristle brush and stored in microtubes with $70 \%$ ethanol. Identification of mites was performed from adult specimens due to the difficulty of secure identification of immature mites.

Mites were identified to the species level whenever possible, although occasionally they were categorized as morphospecies, following classification proposed by Krantz and Walter (2009). Identification of oribatid mites was done by whitening with lactic acid. Firstly, part of the alcohol in the tubes was removed and 4-5 drops of lactic acid were added. Then, the tubes were kept for 5-6 days in an oven at about $55^{\circ} \mathrm{C}$ to optimize the whitening process. The specimens were identified under a phase-contrast microscope using the identification keys of Balogh and Balogh (1988, 1990, 1992) and Norton and Behan-Pelletier (2009), supplemented by descriptions of the species. The classification system used was Subías (2015).

\section{Data analyses}

Analyses were performed considering data values sorted by trees and month. Metacommunity structure analyses were carried out based on the following variables: observed richness, total abundance, phytophagous and non-phytophagous abundance, species turnover (beta diversity) and species composition. For the latter, we first performed an analysis of similarity (ANOSIM), using the function "anosim" available in the package vegan, based on Sorensen matrix distance, with an associated R-value. Moreover, considering the spatial metacommunity turnover, we estimated the mean rate $( \pm S E)$ of species substitution between periods for each tree, and the mean turnover rates among trees (local scale) and among metacommunities (regional scale). This way, if the mean rate of species substitution between periods was superior to the mean turnover within the metacommunity, we assume that day and night species represent different communities of mites. The tests were performed based on Sorensen's index estimated for the communities with all species included, and, secondarily, for the communities without rare species (singletons), but the results did not differ.

For the remaining community attributes, we used a generalized linear mixed model (GLMM) to investigate the importance of underlying factors over each dependent variable, that is, observed richness, total abundance, and phytophagous and non-phytophagous abundance. Thus, we elaborated five alternative models that corresponded to different hypothesis a priori, that considered the relative importance and interaction of time period (day and night) with climate (temperature and relative humidity), and seasonality (months), over each response variable (Table 1). Relative humidity was considered a pretending variable and removed from the models due to the increase of noise in the analysis, so the models that had this variable included seemed penalized towards others (Anderson 2008). Considering spatial autocorrelation, the variable "site" was taken as a random effect and included in all models (Zuur et al. 2009), nonetheless we also assumed the Poisson distribution of the error (Bolker et al. 2009) due to the count response variables.

For each alternative model, we calculated the Akaike information criterion (AIC) (Akaike 1974) using the function ICtab available in the package bbmle (Bolker 2008). We also estimated the difference between the AIC of each model and the lowest AIC value $\left(\triangle \mathrm{AIC}_{i}=\mathrm{AIC}_{i} \square \mathrm{AIC} C_{\mathrm{min}}\right)$, therefore the best model has $\triangle \mathrm{AIC}=0 . \mathrm{We}$ estimated the relative weight of each model (WAIC), which represents the likelihood that a given model is the best within a set of concurrent models (Johnson and Omland 2004). Models with $\triangle \mathrm{AIC} \leq 2$ and WAIC $\geq 0.10$ were considered plausible to explain the observed data (Burnham and Anderson 2002). Taking into account the best models, we also tested their terms for significance a posteriori. All calculations were performed using the programme $\mathrm{R}$ version 3.2.0 ( $\mathrm{R}$ Core Team 2015).

To investigate if day periods could differentially influence the foraging behaviour of mite species, we examined the annual fluctuation of most abundant species of predators and phytophagous mites and tested them for the set of explanatory variables. As performed for community attributes, we carried out GLMM analysis in order to investigate the underpinning factors influencing the seasonal variation in the abundance of these species. Therefore, we considered the previous models (Table 1) to test the strength of our hypothesis on the most abundant species. For model selection, we followed the methodology applied for community structure variables, which consisted in the comparison of AIC and wAIC values of each model, and a significance test for the terms.

Table 1. Fixed and random parameters comprised in each hypothesized model

\begin{tabular}{llc}
\hline Models & \multicolumn{1}{c}{ Fixed variables } & Random \\
\hline M1 & Period + temperature + month & Area \\
M2 & Period + temperature & Area \\
M3 & Period + month & Area \\
M4 & Month & Area \\
M5 & Period & Area \\
\hline
\end{tabular}




\section{Results}

\section{Metacommunity analysis}

A total of 17,749 mites were recorded on Brazilian genipap leaves, of which 10,117 came from daytime samples and 7632 from night-time samples. From this total, 13,763 corresponded to mature mites belonging to 59 species from 24 families (Appendix). In general terms, we found that most of the evaluated metacommunity parameters were mainly influenced by seasonality and time period. In the diurnal period, we recorded a slightly higher richness and abundance per tree (Table 2). Otherwise, species composition remained similar in both periods ( $R=-0.036$ and $p=0.887$ ), even whether the composition of phytophagous and non-phytophagous mites were analysed independently. Similarly, species turnover between daytime and night-time was bounded between $20 \%$ and $35 \%$, whereas mean turnover among trees in the sites (local scale) varied between $30 \%$ and $45 \%$, reaching $60 \%$ among metacommunities (regional scale) (Figure 1).

Investigating species richness, we noticed that besides the slight influence of period, its variation was also driven by seasonality and secondarily by temperature. Period and seasonality comprise the factors of the most parsimonious fitted model (M3), but the secondary model (M1), which included temperature, may be also considered due to its low $\triangle$ AIC value (Table 3 ). In this way, we found that temperature had a negative influence over richness, with fitted values of each period differing in the slope and intercept (Figure 2A). Moreover, species richness varied on a monthly basis, with maximum mean of six species per tree in August, and minimum of two from October to December.

Underlying processes driving total mite abundance may be limited to seasonality and period (M3), since in the secondary

Table 2. Mean values $( \pm \mathrm{SE})$ of the community parameters (richness and abundance), and species density estimated per tree/month on day and night period. Parameters estimated for three sites in São José do Rio Preto, Brazil, between July 2012 and June 2013.

\begin{tabular}{lrccc}
\hline & \multicolumn{1}{c}{ Day } & Night & & \\
\cline { 2 - 3 } Variable & \multicolumn{1}{c}{ Mean $( \pm$ SE $)$} & Mean $( \pm$ SE $)$ & F value & $p$-Value \\
\hline Richness & $6.20( \pm 0.15)$ & $5.91( \pm 0.16)$ & 6.417 & 0.011 \\
Total Abundance & $41.82( \pm 2.37)$ & $32.18( \pm 2.14)$ & 8.67 & 0.003 \\
Euseius citrifolius & $8.23( \pm 0.75)$ & $6.03( \pm 0.57)$ & 17.727 & 0.001 \\
Euseius concordis & $6.27( \pm 0.59)$ & $5.00( \pm 0.68)$ & 7.095 & 0.008 \\
Agistemus floridanus & $2.58( \pm 0.40)$ & $4.09( \pm 0.76)$ & 4.085 & 0.04 \\
Brevipalpus phoenicis & $5.29( \pm 0.86)$ & $4.55( \pm 0.87)$ & 0.429 & 0.513 \\
\hline
\end{tabular}

Analysis of Variance (ANOVA). model (M1) temperature did not show any influence over abundance. Thus, similarly to species richness, the peak of mite abundance was observed in September and the lowest values in January. Decoupling the abundance of phytophagous and nonphytophagous species from the total, we observed that month (M4), representing the annual seasonality was the main driver of phytophagous abundance, whereas M1 (full model) had the best fitting values for non-phytophagous. In this case, the temperature had distinct effects on the abundance, being null during the day and negative at night (Figure 2B). Nonetheless, we noticed a strong effect of period on non-phytophagous mites, but not on phytophagous (Table 3).

\section{Population dynamics}

Regarding the most abundant species according to their feeding habitat, the predatory mites, such as Euseius citrifolius Denmark \& Muma and $E$. concordis (Chant) had a higher mean abundance during the day $\left(F_{1,190}=17.727, p<0.001\right.$, and $F_{1,176}=7.095$, $p=0.008$, respectively), whereas Agistemus floridanus Gonzalez were largely sampled overnight $\left(F_{1,120}=4.085, p=0.04\right)$ (Table 2 , Figure 3 ). Testing the possible effect of the whole set of explanatory variables over the abundance of each species, models including time period and month or their interaction were mostly selected against others. So for E. citrifolius and E. concordis, the model selected was M3 (month and day period), meanwhile, for A. floridanus, the selected model was M4 (month), but was closely similar to M3 (month and period) (Table 4).

The phytophagous species Brevipalpus phoenicis (Geijskes) was not affected by period, and its abundance on the leaves did not vary between day and night samplings $\left(F_{1,145}=0.429, p=0.513\right)$ (Table 2, Figure 3). Thus, from the model selection, we assumed that the seasonal variation, indicated by model M4, was the main factor driving the abundance throughout the year (Table 4). Furthermore, none of the climatic parameters were important for this species.

\section{Discussion}

In summary, we can highlight that time period plays an important role, particularly on the abundance of some predator species populations. However, in terms of metacommunity structure and dynamics, day and night periods seemed not to affect species composition. Complementary to this, seasonal variation was a key parameter in all best-fitting models, regardless of whether it was a community or population analysis. Climatic factors had a low importance for most response variables evaluated, except for

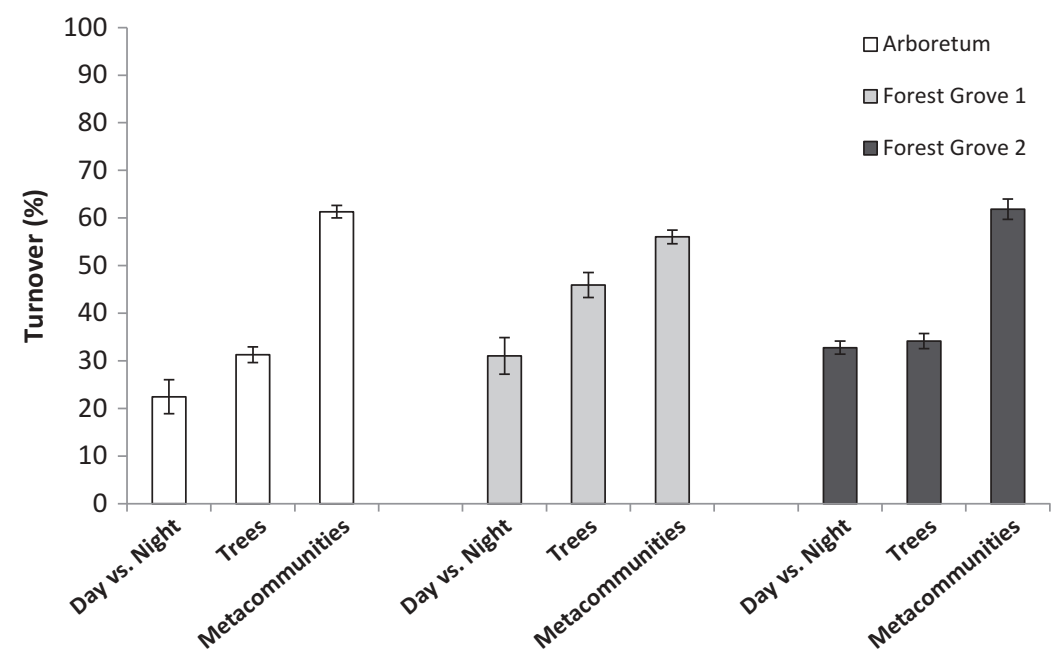

Figure 1. Mean turnover rates $( \pm \mathrm{SE})$ for species composition estimated at different scales, considering the three sites: (a) day vs. night, between day and night-time samplings (at the tree level); (b) trees, among trees within metacommunity (at the site level) and (c) metacommunities, among metacommunities (at landscape level), based on Sorensen's distance. 
Table 3. Summary of generalized linear mixed models (GLMMs) tests for the following metacommunity parameters: richness, total abundance, phytophagous abundance and non-phytophagous abundance.

\begin{tabular}{|c|c|c|c|c|c|c|c|c|c|}
\hline Richness & AIC & $\Delta \mathrm{AIC}$ & df & wAIC & Phytophagous abundance & AIC & $\Delta \mathrm{AIC}$ & df & wAIC \\
\hline${ }^{1} \mathrm{M} 3$ & 1.897 .823 & 0.0 & 15 & 0.665 & ${ }^{2} \mathrm{M} 4$ & 1360.938 & 0 & 14 & 0.768 \\
\hline M1 & 1899307 & 1.5 & 16 & 0.316 & M3 & 1363.404 & 2.5 & 15 & 0.224 \\
\hline M4 & 1904974 & 7.2 & 14 & 0.019 & M1 & 1370.143 & 9.2 & 16 & 0.007 \\
\hline M5 & 2123338 & 225.5 & 4 & $<0.001$ & M2 & 1502.769 & 141.8 & 5 & $<0.001$ \\
\hline Total abundance & AIC & $\triangle A I C$ & df & wAIC & Non-phytophagous abundance & AIC & $\triangle \mathrm{AIC}$ & df & wAIC \\
\hline${ }^{3} \mathrm{M} 3$ & 4642.168 & 0.0 & 15 & 0.514 & ${ }^{4} \mathrm{M} 1$ & 4536.767 & 0.0 & 16 & 0.579 \\
\hline M5 & 4655.378 & 13.2 & 14 & $<0.001$ & M4 & 4536.711 & 9.9 & 14 & 0.004 \\
\hline M2 & 4783.508 & 141.3 & 5 & $<0.001$ & M2 & 4666.660 & 129.9 & 5 & $<0.001$ \\
\hline M4 & 4791.074 & 148.9 & 4 & $<0.001$ & M5 & 4673.350 & 136.6 & 4 & $<0.001$ \\
\hline
\end{tabular}

${ }^{1}$ Period: $F_{1,489}=11.408, p<0.001 ;$ Month: $F_{11,489}=29.827, p<0.001$

${ }^{2}$ Month: $F_{11,467}=18.809, p<0.001$

${ }^{3}$ Period: $F_{1,466}=11.322, p<0.001 ;$ Month: $F_{11,466}=11.325, p<0.001$

${ }^{4}$ Period: $F_{1,465}=7.377, p=0.007$; Temperature: $F_{1,465}=9.810, p=0.002$; Month: $F_{11,465}=9.367, p<0.001$

The variables retained in the most parsimonious models were tested for significance $(F$-values and $p<0.05)$

$\mathrm{Al}: C$ Akaike information criterion; df: degrees of freedom; $\triangle \mathrm{AIC}$ : difference between the AIC of a given model and the best model; wAIC: Akaike weight, measures model strength. $\mathrm{M} 1=$ Period + temperature + month; $M 2=$ Period + temperature; $M 3=$ Period + month; M4 = Month; M5 = Period.
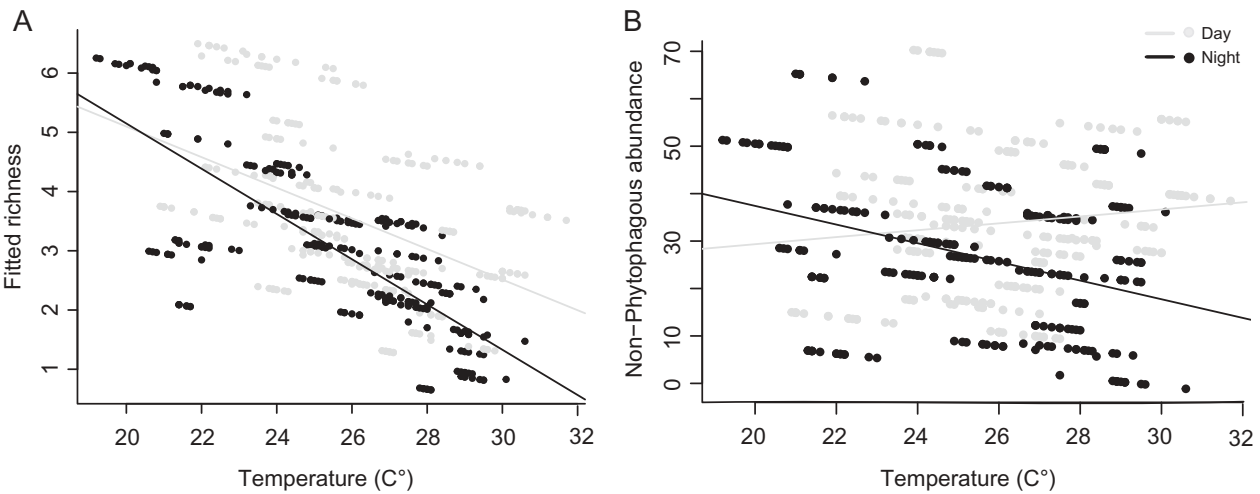

Figure 2. Relationship between temperature and fitted values of richness (A) (output of M1), at day $\left(y=12.789-0.382^{*} x, R 2=0.227, p<0.001\right)$ and at night-time $\left(y=10.267-0.258^{*} x, R 2=0.579, p<0.001\right)$. Relationship between temperature and non-phytophagous abundance (B) (output of $\left.M 1\right)$, at day $\left(y=14.578+0.737^{*} x\right.$, $\mathrm{R} 2=0.015, p=0.054)$ and at night-time $\left(y=76.767-1.967^{*} x, \mathrm{R} 2=0.128, p<0.001\right)$ in three sites of São José do Rio Preto, Brazil, from July 2012 to June 2013 .

Table 4. Summary of generalized linear mixed models (GLMMs) tests for the most abundant species of predators and phytophagous mites: Euseius citrifolius, Euseius concordis, Agistemus floridanus and Brevipalpus phoenicis.

\begin{tabular}{|c|c|c|c|c|c|c|c|c|c|}
\hline E. citrifolius ${ }^{\mathrm{Pr}}$ & $\mathrm{AIC}$ & $\triangle \mathrm{AIC}$ & $\mathrm{df}$ & wAIC & E. concordis ${ }^{\mathrm{Pr}}$ & AIC & $\triangle \mathrm{AIC}$ & $\mathrm{df}$ & wAIC \\
\hline${ }^{1} \mathrm{M} 3$ & $2,869.020$ & 0.0 & 15 & 0.840 & ${ }^{2} \mathrm{M} 3$ & $2,858.894$ & 0.0 & 15 & 0.580 \\
\hline M1 & $2,872.233$ & 3.4 & 16 & 0.160 & M1 & $2,859.903$ & 1.2 & 16 & 0.320 \\
\hline M4 & $2,888.864$ & 19.7 & 14 & $<0.001$ & M4 & $2,862.502$ & 3.4 & 14 & 0.100 \\
\hline M5 & $2,913.690$ & 43.5 & 4 & $<0.001$ & M2 & 2,898.309 & 38.5 & 5 & $<0.001$ \\
\hline M2 & $2,918.853$ & 48.7 & 5 & $<0.001$ & M5 & $2,916.342$ & 56.3 & 4 & $<0.001$ \\
\hline A. floridanus $^{\mathrm{Pr}}$ & AIC & $\triangle \mathrm{AIC}$ & df & wAIC & B. phoenicis ${ }^{\mathrm{Ph}}$ & AIC & $\triangle \mathrm{AIC}$ & df & wAIC \\
\hline${ }^{3} \mathrm{M} 4$ & $2,551.040$ & 0.0 & 14 & 0.520 & ${ }^{4} \mathrm{M} 4$ & $2,987.764$ & 0.0 & 14 & 0.541 \\
\hline M3 & $2,551.181$ & 0.3 & 15 & 0.440 & M3 & $2,988.557$ & 1.0 & 15 & 0.336 \\
\hline M1 & $2,555.827$ & 5.1 & 16 & 0.040 & M2 & 2,991.497 & 3.9 & 15 & 0.077 \\
\hline M2 & $2,569.593$ & 17.6 & 5 & $<0.001$ & M1 & $2,992.362$ & 4.9 & 16 & 0.046 \\
\hline M5 & $2,579.138$ & 27.1 & 4 & $<0.001$ & M5 & $3,042.770$ & 54 & 4 & $<0.001$ \\
\hline
\end{tabular}

${ }^{1}$ Period: $F_{1,476}=22.303, p<0.001 ;$ Month: $F_{11,476}=4.892, p<0.001$

${ }^{2}$ Period: $F_{1,476}=5.828, p=0.016$; Month: $F_{11,476}=6.189, p<0.001$

${ }^{3}$ Month: $F_{11,477}=3.938, p<0.001$

${ }^{4}$ Month: $F_{11,477}=5.564, p<0.001$

The variables retained in the most parsimonious models were tested for significance ( $F$-values and $p<0.05)$.AlC: Akaike information criterion; df: degrees of freedom; $\triangle \mathrm{AIC}$ : difference between the AIC of a given model and the best model; wAIC: Akaike weight, measures model strength. $\mathrm{M} 1=$ Period + temperature +

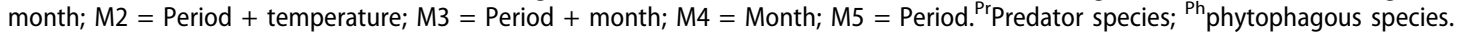

richness that was negatively influenced by temperature, and the abundance of non-phytophagous species which were negatively affected at night.

Our results show that, in plant leaves, mite richness can be somewhat superior in day time period. Thus, despite the small difference between periods, there may be a true tendency for a higher number of species to forage on the leaves during the day and this may not be due to a sampling artefact. For ground hunter spiders (Pinto-Leite and Rocha 2012), it was shown that a greater number of species forages at night with a significant 

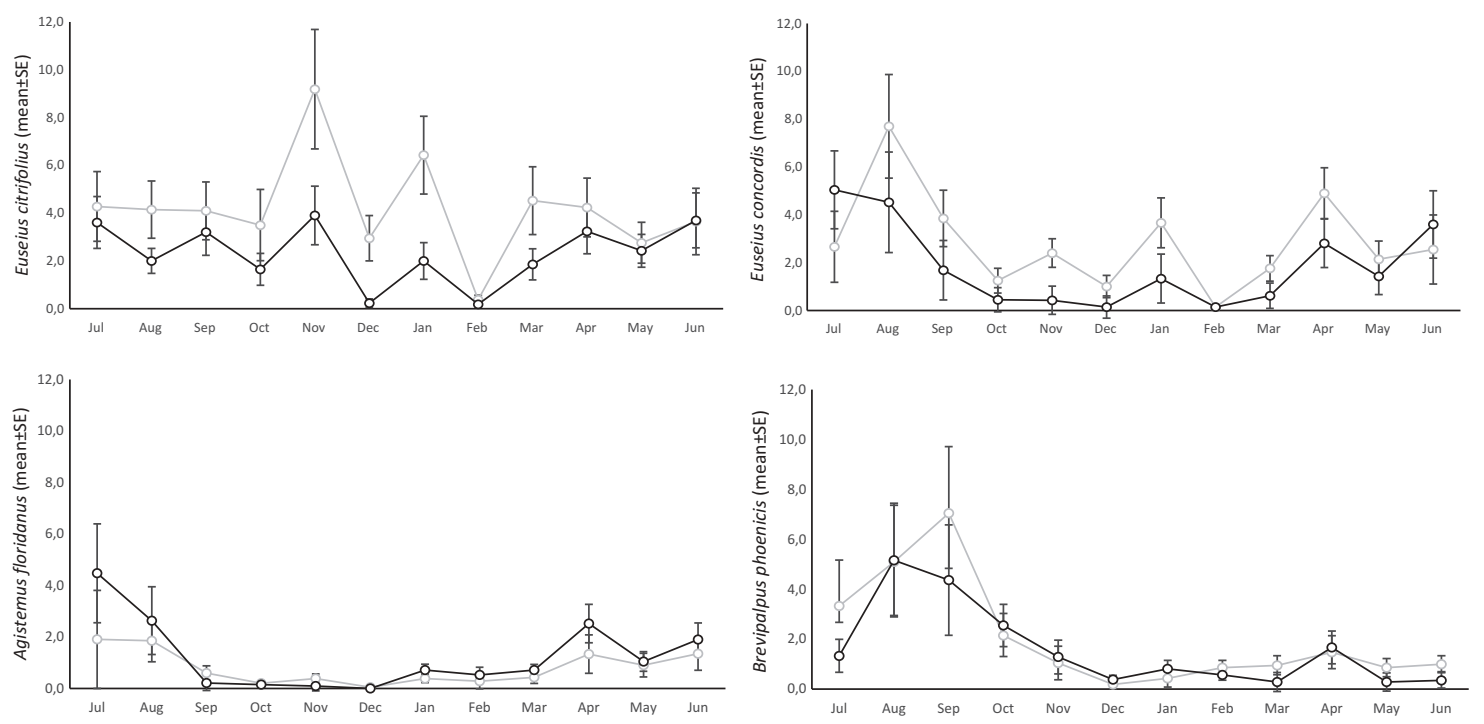

- Day

Figure 3. Seasonal abundance (mean \pm SE) of Euseius citrifolius, Euseius concordis, Agistemus floridanus and Brevipalpus phoenicis at day and night time, from three sites in São José do Rio Preto, Brazil, from July 2012 to June 2013.

composition difference (Costello and Daane 2005). Laboratory experiments have detected behavioural variations in the predatory mites Neoseiulus cucumeris (Oudemans) at distinct periods, that is, their preference to forage on different parts of the plant according to the light incidence (Weintraub et al. 2007).

Considering the effect of climatic factors, we could track a negative influence of temperature on the species richness, suggesting that many species may avoid foraging on the leaves in warmer temperatures $\left(30-32^{\circ} \mathrm{C}\right)$. Under these conditions, we assume they may look for refuges or shelter that could provide a more suitable microclimate in contrast with the leaves, which are usually hotter and drier (Onzo et al. 2003, 2010). Similarly, higher temperatures also have limited the abundance of nonphytophagous mites on the leaves.

The low level of species substitution between day and night periods suggest that the same mite species can be found on a given tree regardless of time period, being part of the same species pool. Notwithstanding, small differences in the species composition between day and night can be due to the sampling bias because different leaves were sampled in each collection event, and also because the samplings were focused only on the mites found on the leaves and petiole, disregarding those on the branches and other parts of the plants. In our study, spatial distance must be considered the most important driver of species turnover, since we noticed a noteworthy increase in the turnover rates accordingly to the increase of spatial scale: from periods (at the tree level), throughout the metacommunity (at the site level), up to the regional level (among sites).

The major influence of the day period was observed at the population level, particularly on the most abundant nonphytophagous species, E. citrifolius, E. concordis and A. floridanus. These mites are assumed active search foragers, found in diverse parts of the plant beyond the leaves (branches, gems and flowers) (Bernstein 1983; Onzo et al. 2003). They have generalist feeding habits, which include pollen, mites, insect eggs and occasionally fungi in their diet (Vis et al. 2006; McMurtry et al. 2013). Apparently, E. concordis, just like E. citrifolius, were easily found in diurnal samplings while the opposite was observed for $A$. floridanus, pointing out that different species can have distinct preferences in foraging time. So, it is possible that the Euseius species and $A$. floridanus avoid one another by foraging at different periods on the same habitat, which may have been induced by intraguild predation risk (Schausberger and Croft 2000). Another hypothesis is that predatory mites can be attracted by herbivore-induced volatiles (HIPVs) released by the leaves
(Nachappa et al. 2007) during the phytophagous feeding process at day (Maeda et al. 2000). In contrast, a counterevidence of Yano and Osakabe (2009) revealed that the HIPVs attraction is not as effective in field experiment as it was in the Y-tube in laboratory. Considering that populations of phytophagous mites were not so abundant on the leaves, we believe that HIPV may have had a secondary importance in the abundance of predatory mites. Likewise, it is more plausible that the differential foraging activity and higher abundance of predatory mites during the day were a behavioural response to microclimate conditions, resource availability and predation risk in spite of HIPVs attraction.

Studies on the dispersion of predatory mites reported that females of Phytoseiulus persimilis Athias-Henriot, Typhlodromus hibisci Chant and T. limonicus Garman \& McGregor could move up to $70 \mathrm{~m} /$ day searching for food and to avoid heat stress (Chant and Fleschner 1960; Sabelis 1981; Bernstein 1983). These results point out that phytoseiid species can migrate long distances searching for food, shelter or more suitable environments. In an opposite way, phytophagous mites remain on the leaf throughout the time and become more susceptible to predation and weather effects; nonetheless, to compensate this, they have a high fertility rate and/or short time generations (Krantz and Lindquist 1979).

Similarly, seasonality was another parameter underlying the dynamics of E. citrifolius. In agreement with Daud and Feres (2005), the greatest abundance of this species throughout the year was recorded in the month of flowering of the host plant species. The pollen supply could be a key resource for Euseius populations, since it is cited as an important item in the diet of species of this genus (Furtado and Moraes 1998; McMurtry et al. 2013).

The abundances of phytophagous species during day and at night showed no differences, unlike that observed for some predators. Considering that $B$. phoenicis is a mite species that shows small mobility and thus the colonization of adjacent leaves is rare (Oomen 1982), it suggests that populations of this species do not move in the Brazilian genipap over the periods of the day. As the seasonality was the main predictor for this species, differences in $B$. phoenicis abundance over the months may be either regulated by physiological changes on genipap leaves, since it is a senescent plant with seasonal replacement of the leaves (Parecis-Silva, pers. inf.) and changes in the climatic conditions throughout the year.

Our results showed that daily periodicity seems not to affect mite species composition like other arthropod groups, for example. However, a major number of mite species were related to daytime only, indicating a preference to this period and/or 
climatic parameter associated. Specifically, the day period configure an important aspect that guild and populations seems to take into account when they forage. Our implications suggest different behavioural patterns among phytophagous and predatory mites, but at the same time an interdependence that regulates their ecological aspects. Apparently, the phytophagous mites remain all the time on the leaves that also provide their food sources and habitat, whereas the predators seemed to have partitioned the habitat, that is, E. citrifolius and E. concordis have a tendency to forage on leaves more frequently during the day, while $A$. floridanus forage at night.

In conclusion, daily periodicity did affect neither species composition nor the metacommunity structure, whereas it had differential effects on the population dynamics of predatory and phytophagous mites. In terms of climatic parameters, milder temperatures have promoted the species diversity as well density of non-phytophagous mites. Apparently, the circadian cycle did not affect abundance of phytophagous mites on the leaves, which remain steady on both periods. In contrast, it seems to drive number of predators found on the leaves, whose species indicate a tendency for habitat partitioning, that is, E. citrifolius and $E$. concordis have a tendency to forage on leaves more frequently during the day, while $A$. floridanus forage at night.

\section{Acknowledgement}

We would like to thank Dr. Antônio Carlos Lofego, Msc. Gustavo C. de O. Piccoli and the members of the "Laboratório de Acarologia" (UNESP/IBILCE) for insightful discussions about the study.

\section{Funding}

This work was partially supported by CAPES, "Coordenacão de Aperfeiçoamento de Pessoal de Nível Superior" Brazil, by scholarship to P.V. Parecis-Silva; by FAPESP, "Fundação de Amparo à Pesquisa do Estado de São Paulo" [Process. 2010/19935-1], by scholarship to F.M. Nuvoloni; and "Conselho Nacional de Desenvolvimento Científico e Tecnológico" (CNPq) [Proc. No 303435/2013-5], by fellowship and research grant to R.J.F. Feres.

\section{References}

Akaike H. 1974. A new look at the Statistical Model Identification. IEEE Trans Automat Contr 19:716-723.

Anderson DR. 2008. Model based inference in the life sciences: a primer on evidence. New York (NY): Springer.

Balogh J, Balogh P. 1988. Oribatid mites of the Neotropical Region I. Amsterdam: Elsevier; 355p.

Balogh J, Balogh P. 1990. Oribatid mites of the Neotropical Region II. Amsterdam: Elsevier; 333p.

Balogh J, Balogh P. 1992. The oribatid mites genera of the world. 2nd ed. Budapest: Hungarian Natural History Museum.

Barcha SF, Arid FM. 1971. Estudo da evapotranspiração na região norte-ocidental do estado de São Paulo. Rev Ciências da Fac Ciências e Let 1:94-122.

Basset Y, Aberlenc HP, Barrios H, Curletti G. 2003. Arthropod diel activity and stratification. In: Basset $\mathrm{Y}$, Novotny $\mathrm{V}$, Miller SE, Kitching RL, editors. Arthropods of tropical forest: spatio- temporal dynamics and resource use in the canopy. Cambridge (UK): Cambridge University Press; p. 304-314.

Bernstein C. 1983. Some aspects of Phytoseiulus persimilis (Acarina: Phytoseiidae) dispersal behavior. Entomophaga 28:185-198.

Bolker BM. 2008. Ecology models and data in R. Princeton (NJ): Princeton University Press; 408p.

Bolker BM, Brooks ME, Clark CJ, Geange SW, Poulsen JR, Stevens MHH, White J-S-S. 2009. Generalized linear mixed models: a practical guide for ecology and evolution. Trends Ecol Evol 24:127-135.

Burnham K, Anderson D. 2002. Model selection and multimodel inference: a practical information-theoretic approach. New
York: Springer. 2nd ed. 515p. Available from: amstat.tandfon line.com.

Carvalho FA, Nascimento MT, Oliveira PP, Rambaldi DM, Fernandes RV. 2004. A importância dos remanescentes florestais da Mata Atlântica da baixada costeira fluminense para a conservação da biodiversidade na APA da Bacia do Rio São João/Mico-LeãoDourado/IBAMA - RJ. An do IV Congr Bras Unidades Conserv 1:106-113.

Castro EB de, Vieira MR. 2011. Acarofauna (Acari, Arachnida) associada a Genipa americana L., (Rubiaceae) em Ilha Solteira, São Paulo. Rev Biol Neotrop 8:33-39.

Chant DA, Fleschner CA. 1960. Some observations on the ecology of phytoseiid mites (Acarina: Phytoseiidae) in California. Entomophaga 5:131-139.

Costello MJ, Daane KM. 2005. Day vs. night sampling for spiders in grape vineyards. J Arachnol 33:25-32.

Daud RD, Feres RJF. 2005. Diversidade e flutuação populacional de ácaros (Acari) em Mabea fistulifera Mart. (Euphorbiaceae) de dois fragmentos de mata estacional semidecídua em São José do Rio Preto, SP. Neotrop Entomol Entomol 34:191-201.

Francis JK. 1993. Genipa americana L. Jagua, genipa. New Orleans (LA): US. Department of Agriculture, Forest Service, Southern Forest experiment Stantion; $5 \mathrm{p}$.

Furtado IP, Moraes GJ de. 1998. Biology of Euseius citrifolius, a candidate for the biological control of Mononychellus tanajoa (Acari: Phytoseiidae, Tetranychidae). Syst Appl Acarol 3:43-48.

Hassan STS, Rashid MM. 1997. Differential diurnal population density ratios of wet rice arthropods in Malaysia. Pertanika J Trop Sci 20:43-49.

Iturralde RB, Trueba DP. 2001. Relationships among vegetation, flora, litter and litter-dwelling microarthropods in a urban forest stand of São José Do Rio Preto, State of São Paulo, Brazil. Rev del Jardín Botánico Nac 22:93-100.

Johnson JB, Omland KS. 2004. Model selection in ecology and evolution. Trends Ecol Evol 19:101-108.

Krantz GW, Lindquist EE. 1979. Evolution of phytophagous mites (Acari). Annu Rev Entomol 24:121-158.

Krantz GW, Walter DE. 2009. A manual of acarology. 3rd ed. Lubbock (TX): Texas Tech University Press; 807 p.

Maeda T, Takabayashi J, Yano S, Takafuji A. 2000. Effects of light on the tritrophic interaction between kidney bean plants, twospotted spider mites and predatory mites, Amblyseius womersleyi (Acari: Phytoseiidae). Exp Appl Acarol 24:415-425.

McMurtry JA, Moraes GJ De, Sourassou NF. 2013. Revision of the lifestyles of phytoseiid mites (Acari: Phytoseiidae) and implications for biological control strategies. Syst Appl Acarol 18:297-320.

Moraes GJ, Flechtmann CHW. 2008. Manual de Acarologia: Acarologia Básica e Ácaros de Plantas Cultivadas no Brasil. Ribeirão Preto: Holos, Editora; 308p.

Nachappa P, Margolies DC, Nechols JR, Loughin T. 2007. Phytoseiulus persimilis response to herbivore-induced plant volatiles as a function of mite-days. Exp Appl Acarol 40:231-239.

Norton RA, Behan-Pelletier VM. 2009. Suborder Oribatida. In: A manual of acarology. 3rd ed. Lubbock (TX): Texas Tech University Press; 807p.

Novotny V, Basset Y, Auga J, Boen W, Dal C, Drozd P, Kasbal M, Isua B, Kutil R, Manumbor M. 1999. Predation risk for herbivorous insects on tropical vegetation: a search for enemy-free space and time. Aust J Ecol 24:477-483.

Onzo A, Hanna R, Zannou I, Sabelis MW, Yaninek JS. 2003. Dynamics of refuge use: diurnal, vertical migration by predatory and herbivorous mites within cassava plants. Oikos 101:59-69.

Onzo A, Sabelis MW, Hanna R. 2010. Effects of ultraviolet radiation on predatory mites and the role of refuges in plant structures. Environ Entomol [Internet]. 39:695-701. Available from: http:// ee.oxfordjournals.org/lookup/doi/10.1603/EN09206

Oomen PA. 1982. Studies on population dynamics of the scarlet mite, Brevipalpus phoenicis, a pest of tea in Indonesia. Wageningen: Med. Landbouwhogeschool 82-1; 98p. 
Pinto-Leite CM, Rocha PLB. 2012. Visual search for tropical web spiders: the influence of plot length, sampling effort, and phase of the day on species richness. Environ Entomol 41:1534-1543.

$R$ Core Team. 2015. R: a language and environment for statistical computing. Vienna (Austria): $\mathrm{R}$ Foundation for Statistical Computing. Available from: http://www.R-project.org/

Rezende JM, Lofego AC. 2011. Phytoseiidae (Acari: Mesostigmata) on plants of the central region of the Brazilian Cerrado. Acarologia 51:449-463.

Romero GQ, Benson WW. 2005. Biotic interactions of mites, plants and leaf domatia. Curr Opin Plant Biol 8:436-440.

Sabelis MW. 1981. Biological control of two-spotted spider mites using phytoseiid predators. Part I: modelling the predator-prey interaction at the individual level. Pudoc, Wageningen: Agricultural Research Report. 242p.

Saigusa M, Oishi K, Ikumoto A, Iwasaki H, Terajima M. 2000. Emergence patterns of small subtidal arthropods in relation to day/night, tidal, and surface/bottom factors: investigations in the Boreal Sea, Japan (Akkeshi, Hokkaido). J Oceanogr 56:295-310.

Schausberger P, Croft B. 2000. Cannibalism and intraguild predation among phytoseiid mites: are aggressiveness and prey preference related to diet specialization? Exp Appl Acarol 24:709-725.
SMA/IF (Secretaria do Meio Ambiente/Instituto Florestal). 2005. Inventário florestal da vegetação natural do Estado de São Paulo. In: Imprensa Oficial do Estado São Paulo, São Paulo. 199p.

Subías LS. 2015. Listado sistemático, sinonímico y biogeográfico de los ácaros oribátidos (Acariformes: Oribatida) del mundo (Excepto fósiles). Vasa 1982:1-570.

Valeri SV, Puerta R, Cruz MCP da. 2003. Efeitos do fósforo do solo no desenvolvimento inicial de Genipa americana L. Sci florestalis 64:69-77.

Vis RMJ de, Moraes GJ de, Bellini MR. 2006. Effect of air humidity on the egg viability of predatory mites (Acari: Phytoseiidae, Stigmaeidae) common on rubber trees in Brazil. Exp Appl Acarol 38:25-32.

Weintraub PG, Kleitman S, Alchanatis V, Palevsky E. 2007. Factors affecting the distribution of a predatory mite on greenhouse sweet pepper. Exp Appl Acarol 42:23-35.

Yano S, Osakabe M. 2009. Do spider mite-infested plants and spider mite trails attract predatory mites? Ecol Res 24:1173-1178.

Zuur A, leno E, Walker N, Saveliev AA, Smith GM. 2009. Mixed effects models and extensions in ecology with R. New York (NY): Springer; 564p.

Appendix. Adult mites recorded on the Brazilian genipap (Genipa americana) leaves at day and night time periods in the three study sites

\begin{tabular}{|c|c|c|c|c|c|c|c|c|}
\hline \multirow[b]{2}{*}{ Family } & \multirow[b]{2}{*}{ Specie } & \multicolumn{2}{|c|}{ Arboretum } & \multicolumn{2}{|c|}{ Forest Grove 1} & \multicolumn{2}{|c|}{ Forest Grove 2} & \multirow[b]{2}{*}{ Total } \\
\hline & & Day & Night & Day & Night & Day & Night & \\
\hline Acaridae & & 63 & 46 & 55 & 165 & 53 & 164 & 546 \\
\hline \multirow{2}{*}{ Ascidae } & Asca sp.1 & & & 1 & & 2 & 2 & 5 \\
\hline & Asca sp.2 & & & & & 1 & & 1 \\
\hline Bdellidae & Spnibdella sp. & & & & & 1 & & 1 \\
\hline Camerobiidae & Neophyllobius trisetosus & 2 & 2 & & 1 & & 1 & 6 \\
\hline \multirow[t]{5}{*}{ Cheyletidae } & Cheletogenes of. ornatus & & & 4 & 5 & & & 9 \\
\hline & Cheletomimus cf. duosetosus & & & 8 & 11 & 5 & 1 & 25 \\
\hline & Chiapacheylus cf. edentatus & & & 10 & 3 & 1 & 1 & 15 \\
\hline & Hemicheyletia aff. bakeri & & 1 & & & & & 1 \\
\hline & Hemicheyletia cf. wellsi & & 1 & 2 & 10 & 9 & 8 & 30 \\
\hline \multirow[t]{7}{*}{ Cunaxidae } & Armascirus aff. albiziae & 1 & & & & 1 & 1 & 3 \\
\hline & Armascirus aff. harrisoni & & 1 & & & & & 1 \\
\hline & Armascirus aff. taurus & & & & & 1 & 1 & 2 \\
\hline & Cunaxa aff. bambusae & & 10 & 45 & 29 & 13 & 8 & 105 \\
\hline & Cunaxa cf. evansi & & & 3 & 2 & & & 5 \\
\hline & Cunaxa cf. lehmane & & & 5 & 11 & & & 16 \\
\hline & Cunaxoides cf. capensis & & & 7 & 5 & & & 12 \\
\hline Eriophyidae & Eriophyes sp. & 1 & & & & 2 & 1 & 4 \\
\hline Erythraeidae & Charletonia sp. & & & & & 1 & & 1 \\
\hline Eupalopsellidae & Exothorhis caudata & & & & & & 1 & 1 \\
\hline Eupodidae & Eupodes sp.1 & & & 1 & 2 & 41 & 31 & 75 \\
\hline Galumnidae & Galumna sp.1 & & & & & 1 & & 1 \\
\hline Iolinidae & Pronematus sp. 1 & 241 & 124 & 40 & 20 & 10 & 22 & 457 \\
\hline Liacaridae & Xenillus sp.1 & & & & & & 1 & 1 \\
\hline Mochlozetidae & Mochlozetes sp.1 & 2 & 1 & 23 & 12 & 1 & & 39 \\
\hline Oribatellidae & Oribatella sp.1 & & 1 & & 1 & 16 & 6 & 24 \\
\hline \multirow[t]{14}{*}{ Phytoseiidae } & Amblyseius acalyphus & & & & & 20 & 14 & 34 \\
\hline & Amblyseius aerialis & & & 9 & & 56 & 48 & 113 \\
\hline & Amblyseius chiapensis & 4 & 3 & 1 & & 190 & 146 & 344 \\
\hline & Amblyseius herbicolus & & & 13 & 17 & & & 30 \\
\hline & Euseius alatus & & & & 1 & & & 1 \\
\hline & Euseius citrifolius & 920 & 536 & 118 & 43 & 12 & 1 & 1630 \\
\hline & Euseius concordis & & & 371 & 278 & 328 & 172 & 1149 \\
\hline & Euseius ho & & & & 7 & 9 & 20 & 36 \\
\hline & Euseius inouei & & & 1 & & & & 1 \\
\hline & Euseius sibelius & 1 & & 3 & 2 & & & 6 \\
\hline & Galendromus annectens & 16 & 10 & 4 & 2 & 1 & & 33 \\
\hline & Iphiseiodes saopaulus & & & & & 3 & 3 & 6 \\
\hline & Iphiseiodes zuluagai & & 1 & 15 & 15 & 187 & 140 & 358 \\
\hline & Neoseiulus tunus & 1 & 1 & 9 & 3 & 2 & & 16 \\
\hline
\end{tabular}


(Continued).

\begin{tabular}{|c|c|c|c|c|c|c|c|c|}
\hline \multirow[b]{2}{*}{ Family } & \multirow[b]{2}{*}{ Specie } & \multicolumn{2}{|c|}{ Arboretum } & \multicolumn{2}{|c|}{ Forest Grove 1} & \multicolumn{2}{|c|}{ Forest Grove 2} & \multirow[b]{2}{*}{ Total } \\
\hline & & Day & Night & Day & Night & Day & Night & \\
\hline & Typhlodromalus marmoreus & & & & & 4 & 3 & 7 \\
\hline & Typhlodromus macrum group & & 1 & 1 & 1 & & & 3 \\
\hline Raphignathidae & Raphignathus sp.1 & 1 & & & & 4 & & 5 \\
\hline Scheloribatidae & Scheloribates sp.1 & & & 1 & 1 & 2 & & 4 \\
\hline \multirow[t]{3}{*}{ Stigmaeidae } & Agistemus floridanus & 62 & 81 & 97 & 168 & 41 & 58 & 507 \\
\hline & Agistemus impavidus & 2 & 1 & & & 22 & 14 & 39 \\
\hline & Primagistemus sp. & & & 4 & 6 & & & 10 \\
\hline Tarsonemidae & & 189 & 47 & 115 & 69 & 25 & 11 & 456 \\
\hline \multirow[t]{5}{*}{ Tenuipalpidae } & Brevipalpus chamaedoreae & & & 159 & 159 & 102 & 120 & 540 \\
\hline & Brevipalpus phoenicis 1 & 263 & 190 & 229 & 179 & 8 & 9 & 878 \\
\hline & Brevipalpus phoenicis 2 & 1 & 3 & 3 & 1 & 3 & 1 & 12 \\
\hline & Brevipalpus cf. tepicbutilonae & 2 & & 2 & & 1 & 1 & 6 \\
\hline & Tenuipalpus anoplus group & 1 & 1 & & & & & 2 \\
\hline \multirow[t]{7}{*}{ Tetranychidae } & Allonychus sp. & & & & 1 & 3 & 2 & 6 \\
\hline & Aponychus sp.1 & & & 1 & & & & 1 \\
\hline & Aponychus sp.2 & & & 1 & & & & 1 \\
\hline & Eotetranychus sp. & 21 & 3 & 40 & 2 & 82 & 81 & 229 \\
\hline & Eutetranychus sp. & 26 & 13 & 14 & 5 & & & 58 \\
\hline & Neotetranychus cf. asper & & & 9 & 1 & & & 10 \\
\hline & Tetranychus sp. & 88 & 16 & 48 & 11 & 37 & 3 & 203 \\
\hline \multirow[t]{2}{*}{ Tydeidae } & Lorryia formosa & 500 & 565 & 197 & 223 & 195 & 158 & 1838 \\
\hline & Tydeus sp. & 301 & 511 & 345 & 134 & 30 & 103 & 1424 \\
\hline Winterschmidtiidae & & 1.007 & 740 & 356 & 238 & 22 & 18 & 2381 \\
\hline Abundance & & 3.716 & 2.910 & 2.370 & 1.844 & 1.548 & 1.375 & 13.763 \\
\hline Richness & & 22 & 24 & 38 & 37 & 40 & 34 & \\
\hline
\end{tabular}

